\title{
生体関門輸送機能を基盤とした疾患メカニズムの解明と治療への展開
}

\author{
伊 藤 慎 悟
}

\section{Elucidation of Disease Mechanisms Based on Transport Function at Tissue Barriers and Challenges in Drug Development}

\author{
Shingo Ito \\ Department of Pharmaceutical Microbiology, Faculty of Life Sciences, Kumamoto University; \\ 5-1 Oe-honmachi, Chuo-ku, Kumamoto 862-0973, Japan.
}

(Received July 10, 2018)

\begin{abstract}
Tissue barriers contribute to the maintenance of homeostasis in the body, and tissue barrier dysfunction presents a risk factor for a variety of diseases. The blood-brain barrier (BBB) is a major tissue barrier acting as a static barrier and dynamic interface that plays an important role in the maintenance of central nervous system homeostasis. We show the functional characterization of the brain-to-blood efflux transport system of amyloid- $\beta$ peptide $(\mathrm{A} \beta)$ across the $\mathrm{BBB}$. We found that activated vitamin D3 may be a candidate agent for modulating the A $\beta$ clearance across the BBB. Cerebral creatine deficiency syndromes are caused by loss-of-function mutations in the creatine transporter (CRT; SLC6A8), which transports creatine at the BBB. We found that functional impairment of CRT due to a G561R mutation resulted in incomplete N-linked glycosylation due to misfolding during protein maturation, leading to impaired creatine transport activity at the BBB. To develop a delivery system for biomedicine across the tissue barrier, we established a screening system to identify cell-penetrating peptides by a combination of in vitro cell permeability screening assays and phage display technology. Using this system, we identified cyclic hepta-peptides that are able to facilitate intestinal absorption of phages in vitro and in vivo, which are promising candidates as a carrier for macromolecular biomedicines. In conclusion, these studies focusing on the dynamic interface of tissue barriers will contribute to knowledge on disease pathogenesis as well as the development of a targeted biomedicine delivery system.
\end{abstract}

Key words_-Alzheimer's disease; blood-brain barrier; cell penetrating peptide; cerebral creatine deficiency syndromes; creatine transporter; drug delivery system

\section{1.はじめに}

生体には末梢と中枢を隔てる血液脳関門（bloodbrain barrier; BBB）や外界と体内を隔てる消化管 バリアなど様々な生体関門がある。生体関門の実体 は，血管内皮細胞や上皮細胞であり，それらが強固 な密着結合による物理的障壁とトランスポーターや 受容体などの物質輸送機構を介した動的インター フェースによるバリア機能を発揮し, 生体の恒常性 維持に重要な役割を果たしている。一方，生体関門 は標的組織への治療薬の送達を妨げる大きな障壁と なつている. 特に, 劇的な治療効果があるバイオ医 薬品は分子量が大きいために生体関門を透過するこ

熊本大学大学院生命科学研究部 (薬学系) 微生物薬学 分野 (下862-0973 熊本市中央区大江本町 5-1)

e-mail: ishingo@kumamoto-u.ac.jp 本総説は, 平成 29 年度日本薬学会九州支部学術奨励賞 の受賞を記念して記述したものである.
とができない. そこで筆者らは，この問題を解決す る方法として新しい細胞膜透過ペプチド（cellpenetrating peptides; CPPs) 同定法を開発し, 消化 管において動的インターフェースを利用したバイオ 医薬品の経口投与を可能にする小腸透過 DNP ペプ チドを同定した。本稿では，生体関門における輸送 機構の解明を発端に疾患の発症原因からバイオ医薬 品のドラッグデリバリー技術開発まで横断的に研究 した成果に関して紹介する.

2. BBB とアルツハイマー病（Alzheimer's disease; AD)

BBB は最も強固なバリア機能を有する生体関門 である. BBB の解剖学的実体は脳毛細血管内皮細 胞がアストロサイトの足突起とペリサイトによって 取り囲まれている脳毛細血管である。この中で脳毛 細血管内皮細胞が強力な密着結合による物理的障壁 とトランスポーターなどの物質輸送機構による動的 


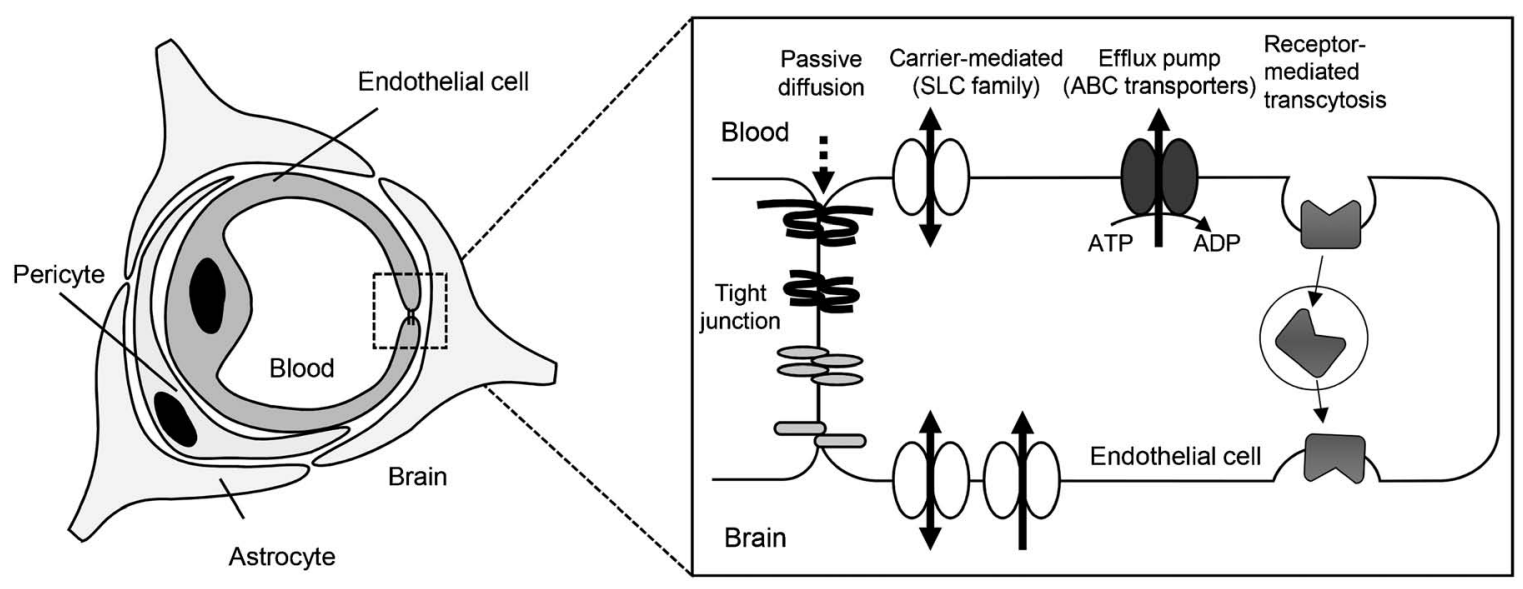

Fig. 1. Structure and Ttransport Model of the Blood-Brain Barrier

インターフェースを介してバリア機能の中心的役割 を果たしている（Fig. 1)。一方で，BBB は選択的 な物質輸送を介して脳機能の恒常性維持に貢献して おり，このBBBにおける輸送機能低下は，認知症 や精神遅滞，てんかんなどで観察されており，

BBB 輸送機能破綻と神経変性疾患発症の関係に注 目が集まっている.

$\mathrm{AD}$ は記憶や知的機能が徐々に失われる老年性認 知症の原因としては最も頻度が高い神経変性疾患で ある。これまでの基礎及び臨床知見から，アミロイ ド $\beta$ ペプチド（amyloid- $\beta$ peptide; $\mathrm{A} \beta$ ）の蓄積が $\mathrm{AD}$ 脳で観察される様々な病理変化の最上流に位置 し，神経細胞の機能障害と脱落の引き金となってい ることが考えられている．脳内 $\mathrm{A} \beta$ 濃度は産生系及 びクリアランス系のバランスによって決定される. ヒトにおいて安定同位体標識法を用いた $\mathrm{A} \beta$ の産生 とクリアランスの速度論的解析から, 遺伝子変異に よらない孤発性 $\mathrm{AD}$ では脳内 $\mathrm{A} \beta$ クリアランスの低 下が脳内 $\mathrm{A} \beta$ 濃度増加の要因であることが示唆され ている. ${ }^{1)}$ 脳内 $\mathrm{A} \beta$ クリアランスは主にネプリライ シンやインスリン分解酵素などの $\mathrm{A} \beta$ 分解酵素によ る分解機構と BBB を介した排出輸送機構によって 担われている．筆者らは $\mathrm{BBB}$ を介した $\mathrm{A} \beta$ 排出輸 送系に着目し，脳内から循環血液中への BBB を介 した物質透過過程を解析できる brain efflux index （BEI）法を用いて BBB を介した $\mathrm{A} \beta$ 排出輸送特性 とそれに係わる分子について検討を行った。 BEI 法 を用いてラット及びマウス大脳皮質に投与された ${ }^{125}$ I-human $\mathrm{A} \beta(1-40)[\mathrm{hA} \beta(1-40)]$ は消失半減期 43-45 分で BBB を介して脳内から消失した. ${ }^{2,3)}$ ま
た， $\mathrm{BBB}$ を介した ${ }^{125} \mathrm{I}-\mathrm{hA} \beta$ （1-40）排出輸送は $\mathrm{AD}$ の最大の危険因子である加齢によって低下した. ${ }^{4,5)}$ 脸から循環血液中への BBB を介した ${ }^{125} \mathrm{I}-\mathrm{hA} \beta$ （140）排出輸送は二量体化やアポリポタンパク質 $\mathrm{E}$ (apoE) と結合することによって減少した。 ${ }^{6}$ 興味 深いことに，ADの遺伝学的危険因子である apoE4 が ${ }^{125} \mathrm{I}-\mathrm{hA} \beta$ （1-40） と結合した場合の脳内からの BBB を介した排出は apoE2 や apoE3 よりも小さい

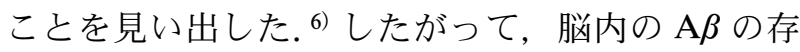
在状態が $\mathrm{BBB}$ を介した $\mathrm{A} \beta$ 排出輸送に影響を与 え, 脳内 $\mathrm{A} \beta$ 濃度の増加に一部寄与していることが 考えられる.

筆者らは BEI 法を用いた解析において，既報の low-density lipoprotein receptor-related protein 1 (LRP-1) や P-glycoprotein（P-gp）は BBB を介し た ${ }^{125} \mathrm{I}-\mathrm{hA} \beta(1-40)$ 排出輸送に対する寄与が小さく, インスリン感受性分子機構が関与することを示し た. ${ }^{2-4,7)}$ そこで，BBBにおけるインスリン感受性分 子を同定するために，マウス脳毛細血管内皮細胞の モデル細胞である TM-BBB4 細胞を用いて BBB に おける ${ }^{125} \mathrm{I}-\mathrm{hA} \beta$ (1-40) 内在化分子を検討した。 そ の結果， TM-BBB4 細胞への ${ }^{125} \mathrm{I}-\mathrm{hA} \beta(1-40)$ 内在 化はインスリンやインスリン分解酵素阻害剤によっ て低下し，ネプリライシン阻害剤によって低下しな かつた. ${ }^{8)}$ また，インスリン分解酵素が TM-BBB4 細胞の細胞膜に発現し，速やかに細胞内に内在化す ることを見い出した。 ${ }^{8)}$ 以上の結果から，BBBに発 現するインスリン分解酵素は hA $\beta$ (1-40) 排出輸 送に関与する分子であることが示唆された.

病態における脳内 $\mathrm{A} \beta$ 増加メカニズムを解明する 
ために, 慢性酸化ストレスを惹起する $\alpha$-tocopherol transfer protein $(\alpha T T P)$ 遺伝子久損マウスにおけ る脳内 $\mathrm{A} \beta$ クリアランスを検討した. ${ }^{5)}$ その結果, $\alpha T T P$ 遺伝子久損マウスにおいて, BBB を介した ${ }^{125} \mathrm{I}-\mathrm{hA} \beta$ （1-40）排出輸送は $28 \%$ 減少することを見 い出した。興味深いことに，BBB を介した ${ }^{125 I-~}$ hA $\beta$ （1-40）排出輸送は減少したにもかかわらず, $\alpha T T P$ 遺伝子久損マウスの脳毛細血管における LRP-1 や P-gp タンパク質発現量は増加していた. また， $\alpha T T P$ 遺伝子欠損マウス脳におけるネプリラ イシン活性は野生型マウス脳と変わらなかったのに 対し, 脳内インスリン分解酵素のタンパク質発現量 は顕著に低下していた。 さらに, $\alpha T T P$ 遺伝子欠損 マウスと $\mathrm{AD}$ モデルマウスを掛け合わせたとこ ろ, 脳内 $\mathrm{A} \beta$ 蓄積は増加し, 行動試験において認知 機能の低下が促進された. ${ }^{9)}$ 以上の知見から，慢性 酸化ストレスによる BBB におけるインスリン分解 酵素の発現低下が脳内 $\mathrm{A} \beta$ 蓄積とそれに伴う認知機 能低下を惹起するメカニズムの 1 つであることが示 唆された。

BBB における $\mathrm{A} \beta$ 排出輸送は加齢によって低下 することから，この低下を回復させることが $\mathrm{AD}$ の発症や進行を抑制することに有効であることが考 えられる、そこで筆者らは，ドラッグ・リポジショ ニングを目指して $\mathrm{BBB}$ を介した $\mathrm{A} \beta$ 排出輸送を促 進させる治療薬を既存薬の中から探索した。その結 果，活性型ビタミン D3 [ 1 $\alpha, 25$-dihydroxyvitamin $\left.\mathrm{D} 3 ; 1 \alpha, 25(\mathrm{OH}){ }_{2} \mathrm{D} 3\right]$ が $\mathrm{BBB}$ における $\mathrm{A} \beta$ 排出輸送 を促進させることによって大脳皮質の $\mathrm{A} \beta$ 濃度を低 下させることを見い出した (Fig. 2).10) 疫学調査に よって血液中 vitamin $\mathrm{D} 3$ 濃度は $\mathrm{AD}$ 患者で低い傾 向にあり, ${ }^{11)} 1 \alpha, 25(\mathrm{OH})_{2} \mathrm{D} 3$ 投与が $\mathrm{AD}$ モデルマウ スの脳内 $\mathrm{A} \beta$ を低下させることが報告されてい

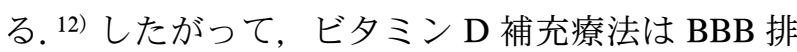
出輸送を標的とした $\mathrm{AD}$ 予防・治療薬となる可能 性があることが考えられる。

\section{BBB と脳クレアチン欠乏症候群}

脳内エネルギーの恒常性維持は神経細胞の発達や 機能発現に必須であり，そのエネルギー物質は主に BBB を介した血液からの供給に依存している。 レアチン（Creatine）は ATP 貯蔵機能を担う物質 であり, $\mathrm{Na}^{+}, \mathrm{Cl}^{-}$を駆動力とする 12 回膜貫通型 トランスポーターであるクレアチントランスポー

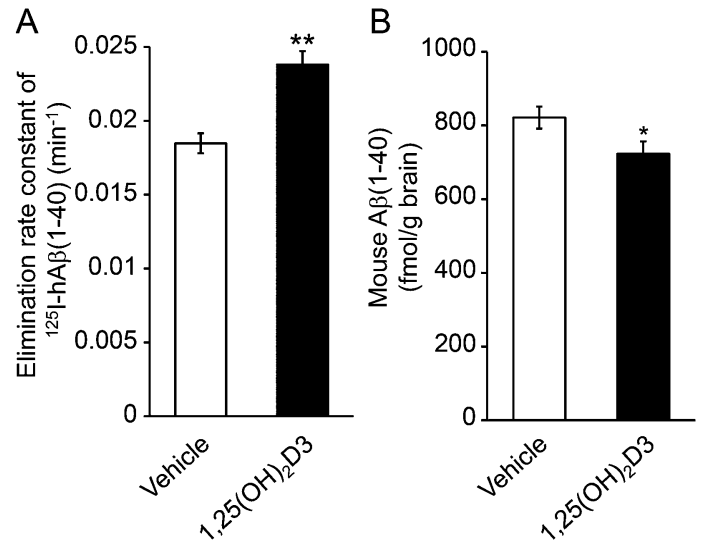

Fig. 2. Effect of $1,25(\mathrm{OH}){ }_{2} \mathrm{D} 3$ on the Elimination of ${ }^{125} \mathrm{I}-\mathrm{hA} \beta$ (1-40) across the Blood-Brain Barrier (A), and the Level of Endogenous Amyloid- $\beta$ Peptide (1-40) in the Mouse Brain (B)

Each point represents the mean \pm S.E.M. $(n=3-8) .{ }^{*} p<0.05,{ }^{* *} p<$ 0.01 , significantly different compared to the vehicle-treated group. This figure was modified from Ito et al., 2010.10)

ター (creatine transporter; CRT, SLC6A8) によつ て輸送される。この $C R T$ 遺伝子の変異は脳内クレ アチンを欠乏させ，知的障害，言語発達遅滞，てん かんを引き起こす脳クレアチン欠乏症候群 (cerebral creatine deficiency syndromes; CCDSs) の 発症原因となる．現在，CCDSs に対する有効な治 療法は開発されておらず（アンメットメディカル ニーズ)，革新的な治療薬の開発が期待されている.

近年，日本人の小児精神遅滞患者から新規変異 $C R T$ 遺伝子 (c.1681 G $>C, G 561 \mathrm{R})$ が見い出さ れ，この $\mathrm{G} 561 \mathrm{R}$ 変異型 $C R T$ 遺伝子を有する患者 の脳内クレアチン濃度は顕著に低下していた。 ${ }^{13)}$ Uniprot におけるトポロジー解析から，CRT 遺伝 子における G561R 変異は CRT の第 12 膜貫通ドメ インに局在することが予想される．CRT と類似構 造をとることが想定される細菌（Aquifex aeolicus） ロイシントランスポーターの構造解析結果から,

CRT の第 1 及び第 6 膜貫通ドメインがクレアチン 結合に必須であると予想されている。したがって, G561R 変異は CRT のクレアチン輸送の活性中心部 位から離れており，直接的な影響を及ぼさないこと が推測される，そこで，G561R 変異型 CRT がクレ アチン輸送を低下させる分子機序を解明するために, $\mathrm{G} 561 \mathrm{R}$ 変異型 $\mathrm{CRT}$ 強制発現細胞を用いた検討を 行った. ${ }^{14)}$ その結果， ${ }^{14} \mathrm{C}$-creatine を用いた輸送実 験において，G561R 変異 CRT によるクレアチン初 期取り込み速度は野生型に比べて $73 \%$ 減少した一 


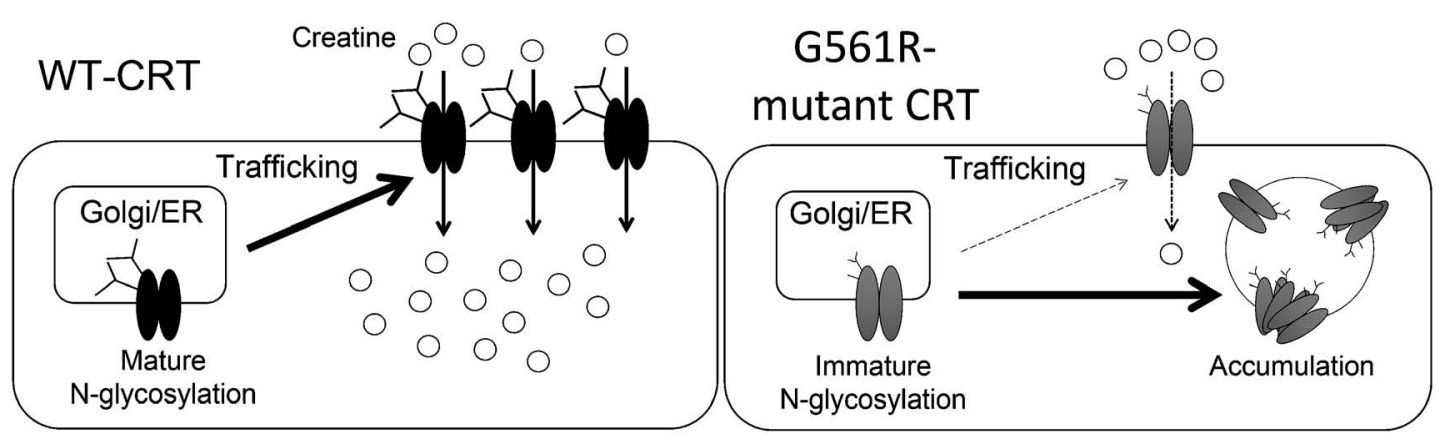

Fig. 3. The Mechanism of Creatine Transport Activity Attenuation by the G561R Mutation

方で, G561R 変異 CRT によるクレアチン取り込み 特性は野生型 $\mathrm{CRT}$ と同様に飽和性と $\mathrm{Na}^{+}-\mathrm{Cl}^{-}$依 存性を示した。免疫組織化学的解析から, 野生型 CRT は主に細胞膜に局在するのに対し, 変異型 CRT は主に細胞内に局在していた。さらに, Western blot 法による CRT タンパク質発現解析に おいて, 野生型 CRT は主に細胞膜画分の $68 \mathrm{kDa}$ にバンド検出されたのに対し，変異型 CRT は主に 粗膜画分の $55,110,165 \mathrm{kDa}$ にバンドが検出され た.これら両細胞の $\mathrm{CRT}$ バンドは脱 $\mathrm{N}$ 型糖鎖反応 によってともに $50 \mathrm{kDa}$ にシフトした．以上の結果 から, G561R 変異型 CRT は CRT タンパク質の未 熟な $\mathrm{N}$ 型結合糖鎖修飾による細胞膜へのメンブラ ントラフィッキングの減少を引き起こし，その結 果, クレアチン輸送活性の低下を引き起こすことが 明らかとなった（Fig. 3)。この研究成果から， G561R 変異型患者において BBB における血液から 脳へのクレアチン供給が著しく低下している可能性 が考えられる.

これまでにCCDSs に対する治療薬開発は，シク ロクレアチンを筆頭にクレアチン類似体を用いた研 究が展開されてきた。今回, 筆者らの研究から CRT タンパク質の糖鎖修飾異常やフォールディン グ，メンブラントラフィッキングを改善させること が CCDSs の治療につながる可能性を見い出した.

CCDSs に関連する遺伝子変異は少なくとも 30 種類 報告されており，その中で活性中心部位から離れた 変異も多数報告されている. ${ }^{15)}$ 既報の強制発現系を 用いた ${ }^{14} \mathrm{C}$-creatine 輸送実験とタンパク質発現解析 の結果から, CRT タンパク質の糖鎖修飾異常や フォールディング, トラフィッキングが異常でクレ アチン輸送活性が失活している変異もあることが予 想される. ${ }^{16)} \mathrm{CCDSs}$ と同様に小児の希少難治性肝
疾患として進行性家族性肝内胆汁うつ滞症がある. この疾患の原因遺伝子である bile salt export pump $(B S E P, A B C B 11)$ 変異体は輸送活性があるものの 肝毛細胆管側膜における発現量が低い。 そこで, BSEP の細胞膜発現量を増加させる作用を有する化 合物の 1 つとして，尿素サイクル異常症の治療薬で ある 4-phenylbutyrate が同定され, ${ }^{17)}$ 現在, 臨床試 験が実施されている. ${ }^{18)}$ 今後, 各種遺伝子変異によ る CRT 活性低下機序を明らかにしていくことが, CCDSs 患者に対する治療薬を開発する上で重要な 情報になると考えられる.

\section{4. バイオ医薬品の経口投与における小腸吸収}

消化管は外界と体内を隔てるバリアであり，消化 管の中でも特に小腸は栄養の吸収や病原菌など外敵 の侵入に対する防御に重要な役割を果たしている. 一方で，消化管から吸収させる経口投与は最も汎用 されている医薬品の投与経路であり，低分子医薬品 に関しては約 $60 \%$ が経口投与薬である. しかし， 劇的な治療効果が期待できるバイオ医薬品であるぺ プチド・タンパク性医薬品や核酸医薬品が増加して きているが, 高分子量であるため, 経口投与で十分 な吸収性や安定性がないことがボトルネックとな り，バイオ医薬品の経口投与は実現していない。し たがって，バイオ医薬品の小腸吸収を改善するド ラックデリバリーシステム（drug delivery system; DDS）の開発は，高分子であるバイオ医薬品の開 発・適応を加速・拡大し, さらに, 患者 QOL を向 上させるために, 創薬領域において重要な課題であ る.

これまでに CPPs がバイオ医薬品の小腸吸収を改 善することが報告されている。例えば，CPPsの 1 種である penetratin を共投与することで，インスリ ンの小腸吸収が改善され，血糖降下作用が観察され 


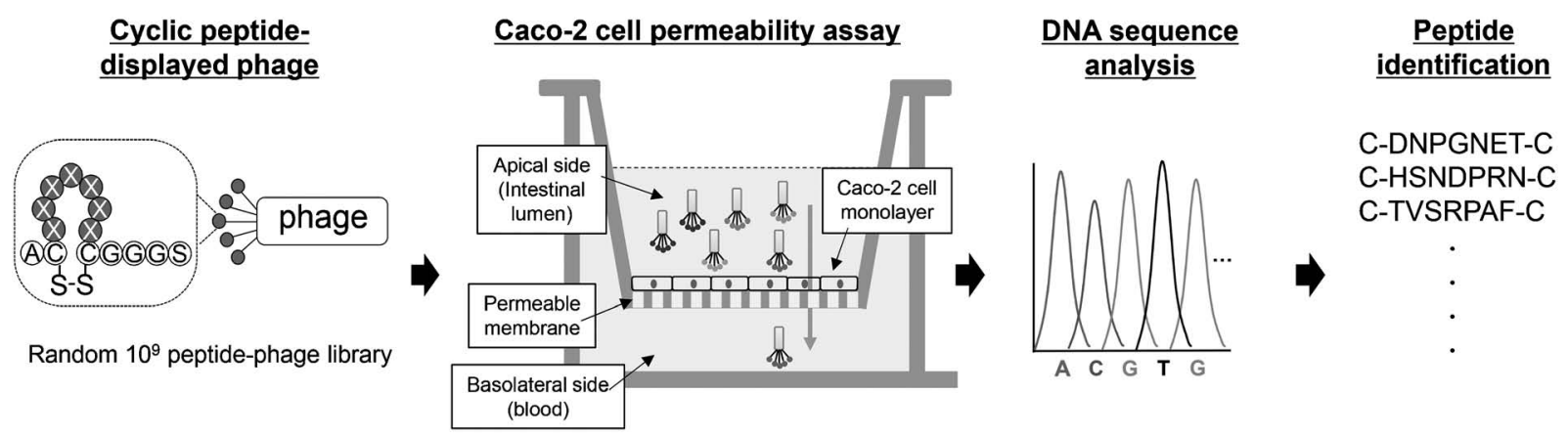

Fig. 4. The Strategy for Discovery of Cyclic Peptides That Promote Intestinal Permeability This figure was modified from Yamaguchi et al., 2017.22)

ている.19) しかし， penetratin や TAT，R8 などの 既存の CPPs は正に帯電しているため, 細胞膜を透 過後，細胞内において負に帯電する細胞内小器官に トラップされ易く，小腸上皮細胞内から循環血中へ

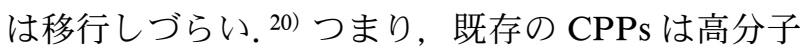
化合物であるバイオ医薬品やナノキャリアと結合さ せることによって細胞膜透過を促進させて細胞内に 効率的に移送することはできるものの, 細胞内から 細胞外への排出が抑制されるために, 経細胞輸送は ほとんど促進させないことが考えられる。実際に, 既存の CPPs を高分子化合物に結合させた場合，小 腸透過が促進されないことが報告されている. ${ }^{21)}$ バ イオ医薬品の小腸吸収促進において求められる CPP の特性は，管腔側から血管側に小腸上皮細胞 を効率的に「透過」させることである。 そこで筆者 らは, phage display 法及びヒト小腸透過モデルと して汎用される Caco-2 細胞透過試験に着目した. Phage（長さ約 $1 \mu \mathrm{m} ）$ はバイオ医薬品（約 $10 \mathrm{~nm}$ ) やナノキャリア（約 $100 \mathrm{~nm}$ ) よりも巨大であるた め, phage を透過させることができればバイオ医薬 品やナノキャリアも透過可能と考え, phage をバイ オ医薬品モデルとした。 また，標的親和性や安定性 に優れる環状ペプチドを提示する phage libraryを 環状ペプチドが結合したバイオ医薬品モデルとし た。この環状ペプチド提示 phage library を Caco-2 細胞透過試験によってスクリーニングすることで, バイオ医薬品の小腸透過を促進する新規小腸透過性 環状ペプチドを同定することを行った（Fig. 4). ${ }^{22)}$ その結果, Caco-2 細胞を透過する 3 種類の 7 アミ ノ酸から構成される環状ぺプチドを同定することに 成功した。特に, DNPGNET（DNP）は塩基性ア ミノ酸（アルギニン，リジン，ヒスチジン）を含ま
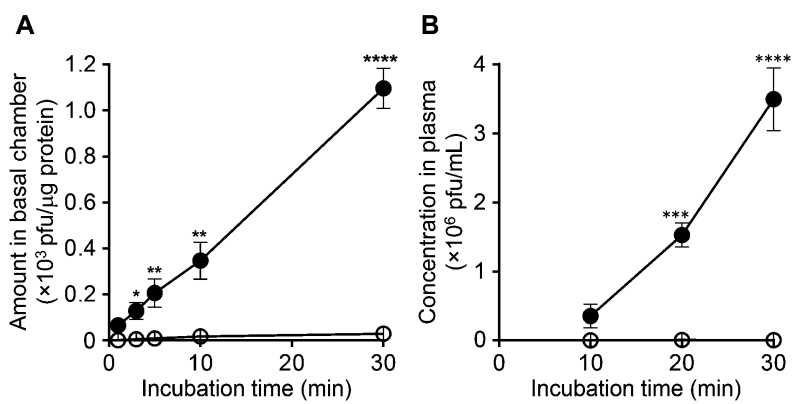

Fig. 5. Time-dependent Transcellular Transport of DNPphage across a Caco-2 Cell Monolayer (A), and Timedependent Plasma Concentration of DNP-phage into a Closed Mouse Intestinal Loop in Situ (B)

Data represents mean \pm S.E.M. $(n=3) .{ }^{*} p<0.05,{ }^{* *} p<0.01,{ }^{* * *} p$ $<0.001,{ }^{* * * *} p<0.0001$, significantly different compared to the control phage. Closed circle, DNP-phage; Open circle, control phage. DNP-phage; cyclic DNPGNET peptide displaying phage, Control phage; no cyclic peptide displaying phage. This figure was modified from Yamaguchi et al., 2017.22)

ず，PI 值は 2.72 であり，消化管内で負に帯電して いることが予想され，既存の CPP とは異なる物性 を持っていた。

次に, 同定した環状ペプチドの輸送解析を行つ た。環状ペプチド DNP 提示 phage（環状 DNPphage）は Caco-2 細胞を最も速く透過し, 添加後 30 分における透過量はペプチドを提示しない control phage と比較して 38 倍高かった [Fig. 5(A)]. また，この環状 DNP-phage が提示するペプチドと 同配列の合成環状 DNP ペプチドを添加することで,

Caco-2 細胞透過量は $51 \%$ 低下した。 次に, in vivo におけるマウス小腸透過能を in situ closed loop 法 を用いて解析した。 その結果，投与後 30 分におけ る血漿中 DNP-phage 濃度は control phage と比較 し，620 倍高かった [Fig. 5(B)]。腸における DNP ペプチドの安全性を Caco-2 細胞を用いて検 討したところ，DNP ペプチドは Caco-2 細胞の生 
存率及び密着結合には影響しなかった。したがつ て，環状ペプチド DNP は安全性の高い新規のバイ 才医薬品の小腸透過を促進させる CPP であること が明らかになった。

以上の結果から，同定した環状ペプチド DNP は 高分子医薬品やナノキャリアよりも巨大な phage の小腸透過を促進させることが明らかになった。ペ プチドはリポソームといつたナノキャリア表面への 修飾が容易である。現在の DNP ペプチドは L 体ア ミノ酸から構成されており，消化管において分解を 受け易い。これまでに，ペプチドを構成するアミノ 酸を L 体から D 体へと置換することで，ペプチド の消化管内における安定性が改善されることが報告 されている，今後，D体化 DNP ペプチドを用いる ことで, 経口投与型バイオ医薬品に適応可能な新規 小腸透過 DDS の開発が期待される.

\section{5. 今後の展望}

生体関門における物質輸送を担うトランスポー ターなどの膜輸送分子の細胞・組織・個体における 恒常性維持への関与は複雑多岐にわたり，これまで に，原因となる膜輸送分子の実体には到達したもの の, 細胞・組織・個体レベルで認められる生理機能 や疾患発症機序の理解にまで至っていないものが多 い. 今後は, 生体関門における 1 つの鍵となる膜輸 送分子の単一分子機能とともにオミクスを駆使して 周辺の膜輸送分子の発現・機能変動や細胞内分子 ネットワークを統合的に解析していくことが必要で あり, 将来, 生体関門の膜輸送分子を標的とした創 薬の実現につなげていきたい.

謝辞本研究の遂行にあたり, 熊本大学大学院 生命科学研究部（薬学系）大槻純男教授, 平山未央 助教, 東北大学大学院薬学研究科 寺崎哲也教授, 立川正憲准教授, 東京医科歯科大学 横田隆徳教授 に深く感謝申し上げます。また，ともに本研究を遂 行してくれた熊本大学薬学部/大学院薬学教育部微 生物薬学分野及び東北大学大学院薬学研究科薬物送 達学分野の学生諸氏に心よりお礼申し上げます。

利益相反＼cjkstart開示すべき利益相反はない.

\section{REFERENCES}

1) Mawuenyega K. G., Sigurdson W., Ovod V., Munsell L., Kasten T., Morris J. C., Yarasheski K. E., Bateman R. J., Science, 330, 1774 (2010).

2) Ito S., Ohtsuki S., Terasaki T., Neurosci. Res., 56, 246-252 (2006).

3) Ito S., Ueno T., Ohtsuki S., Terasaki T., $J$. Neurochem., 113, 1356-1363 (2010).

4) Shiiki T., Ohtsuki S., Kurihara A., Naganuma H., Nishimura K., Tachikawa M., Hosoya K., Terasaki T., J. Neurosci., 24, 9632-9637 (2004).

5) Nishida Y., Ito S., Ohtsuki S., Yamamoto N., Takahashi T., Iwata N., Jishage K., Yamada H., Sasaguri H., Yokota S., Piao W., Tomimitsu H., Saido T. C., Yanagisawa K., Terasaki T., Mizusawa H., Yokota T., J. Biol. Chem., 284, 33400-33408 (2009).

6) Ito S., Ohtsuki S., Kamiie J., Nezu Y., Terasaki T., J. Neurochem., 103, 2482-2490 (2007).

7) Ito S., Matsumiya K., Ohtsuki S., Kamiie J., Terasaki T., J. Cereb. Blood Flow Metab., 33, 1770-1777 (2013).

8) Ito S., Ohtsuki S., Murata S., Katsukura Y., Suzuki H., Funaki M., Tachikawa M., Terasaki T., J. Alzheimers Dis., 38, 185-200 (2014).

9) Nishida Y., Yokota T., Takahashi T., Uchihara T., Jishage K., Mizusawa H., Biochem. Biophys. Res. Commun., 350, 530-536 (2006).

10) Ito S., Ohtsuki S., Nezu Y., Koitabashi Y., Murata S., Terasaki T., Fluids Barriers CNS, 8, 20 (2011).

11) Littlejohns T. J., Henley W. E., Lang I. A., Annweiler C., Beauchet O., Chaves P. H., Fried L., Kestenbaum B. R., Kuller L. H., Langa K. M., Lopez O. L., Kos K., Soni M., Llewellyn D. J., Neurology, 83, 920-928 (2014).

12) Durk M. R., Han K., Chow E. C., Ahrens R., Henderson J. T., Fraser P. E., Pang K. S., J. Neurosci., 34, 7091-7101 (2014).

13) Kato H., Miyake F., Shimbo H., Ohya M., Sugawara H., Aida N., Anzai R., Takagi M., 
Okuda M., Takano K., Wada T., Iai M., Yamashita S., Osaka H., Brain Dev., 36, 630633 (2014).

14) Uemura T., Ito S., Ohta Y., Tachikawa M., Wada T., Terasaki T., Ohtsuki S., Biol. Pharm. Bull., 40, 49-55 (2017).

15) van de Kamp J. M., Mancini G. M., Salomons G. S., J. Inherit. Metab. Dis., 37, 715-733 (2014).

16) Betsalel O. T., Pop A., Rosenberg E. H., Fernandez-Ojeda M., Jakobs C., Salomons G. S., Mol. Genet. Metab., 105, 596-601 (2012).

17) Hayashi H., Sugiyama Y., Hepatology, 45, 1506-1516 (2007).

18) Ito S., Hayashi H., Sugiura T., Ito K., Ueda H., Togawa T., Endo T., Tanikawa K., Kage
M., Kusuhara H., Saitoh S., Pediatr. Int., 58, 506-509 (2016).

19) Kamei N., Morishita M., Kanayama Y., Hasegawa K., Nishimura M., Hayashinaka E., Wada Y., Watanabe Y., Takayama K., J. Control. Release, 146, 16-22 (2010).

20) Lindgren M. E., Hällbrink M. M., Elmquist A. M., Langel U., Biochem. J., 377, 69-76 (2004).

21) Kristensen M., de Groot A. M., Berthelsen J., Franzyk H., Sijts A., Nielsen H. M., Bioconjug. Chem., 26, 477-488 (2015).

22) Yamaguchi S., Ito S., Kurogi-Hirayama M., Ohtsuki S., J. Control. Release, 262, 232-238 (2017). 